\title{
The impact of nutritional choices on global warming and policy implications: examining the link between dietary choices and greenhouse gas emissions
}

\author{
This article was published in the following Dove Press journal: \\ Energy and Emission Control Technologies \\ 9 December 2014 \\ Number of times this article has been viewed
}

\author{
Andrew Joyce' \\ Jonathan Hallett ${ }^{2}$ \\ Toni Hannelly ${ }^{2}$ \\ Gemma Carey ${ }^{3}$ \\ 'Centre for Social Impact Swinburne, \\ Swinburne University of Technology, \\ Hawthorn, VIC, Australia; ${ }^{2}$ School \\ of Public Health, Curtin University, \\ Bentley, WA, Australia; ${ }^{3} \mathrm{National}$ \\ Centre for Epidemiology and \\ Population Health, The Australian \\ National University, Canberra, ACT, \\ Australia
}

\begin{abstract}
Research over the past 10 years has illustrated an important connection between dietary choices, the food systems required to produce them, and the subsequent impact on greenhouse gas (GHG) emissions. Several recent studies have used data on the GHG contribution of different food types to model the impact of different dietary patterns on GHG emissions; these studies have most commonly compared the average diet for a particular country to healthier dietary options and vegetarian options. We present a systematic review of this research that models different dietary choices and the associated GHG emissions with the main aim in this paper of contrasting the research implications for policy and practice. A database search of CINAHL, ScienceDirect, Scopus, Web of Science, ProQuest, Cochrane Database of Systematic Reviews, and Mednar in July 2014 identified 21 primary studies modeling the GHG emissions related to a dietary pattern published since 1995 . Diets containing a higher ratio of plant to animal products were generally associated with lower GHG emissions; however, the results varied across countries and studies, as did the recommendations by the study authors. Some authors proposed leading with health messages that have a dual environmental gain, whereas others proposed messaging around environmental impact. These inconsistencies in recommended approaches to reduce diet-related GHG emissions relate not just to differences in research findings but also to assumptions about community and political support for action, and there is little empirical evidence on community knowledge, attitudes, and behavioral intention at present to support these recommendations. The paper concludes with a commentary on the policy implications and the need for further research on how to frame the issue so as to garner community and political support to address the leading recommendations of this research.
\end{abstract}

Keywords: diet, climate change, policy

\section{Introduction}

Climate change is recognized as a significant public health issue, and its impact on food security is a major area of concern. ${ }^{1,2}$ In the second half of the 20th century, food production more than doubled in response to growing populations, ${ }^{3}$ however, this increase led to degradation of land, loss of biodiversity, changes in climate, and increases in resource inputs' demands on the food system. ${ }^{4}$ The production and consumption of food requires a large amount of resources, including land, water, minerals, and energy, and results in substantial emissions of greenhouse gases (GHGs). ${ }^{5}$ Furthermore, from the projections of variability in climatic conditions, without adequate solutions, we can anticipate a loss in agricultural productivity, crop yields, pasture growth, livestock production, and economic returns, as well as an increase in agricultural production 
costs. $^{6}$ These effects on the food system will have considerable long-term impacts on the environment and public health, making it more difficult to achieve food security. ${ }^{2}$

Just as climate change can affect our diet and nutritional status, so our dietary choices and the food systems required to produce them affect the levels of GHG emissions and, subsequently, climate change. According to Garnett, ${ }^{7}$ the levels of GHG emissions associated with food production are on par with those produced by the transport sector, which is usually seen as one of the major GHG contributors. About one-fifth of all GHG emissions attributable to the $\mathrm{UK}^{8,9}$ and Australia $^{10}$ have been estimated to be derived from food production (including processing, packaging, and transport) and consumption. Vermeulen et $\mathrm{al}^{11}$ conducted a thorough review of the impact of the food system on climate change and how climate change itself will affect the food system. Most GHG emissions associated with the food system occur at the production stage; however, emissions also occur in other parts of the food chain, such as preproduction (eg, fertilizer manufacturing) and postproduction such as refrigeration, transport, and waste.

The type of food produced (animal based or plant based) has a large bearing on GHG emission levels. Estimates of the GHG impact of different food types have enabled modeling of different dietary patterns on GHG emissions; these studies have tested a range of dietary scenarios typically comparing the average diet for a particular country to healthier dietary options and vegetarian options. This paper examines this research particularly focusing on the conclusions reached and the policy and program implications of this research.

\section{Search strategy}

A systematic electronic search was conducted in July 2014 to identify relevant publications from the following databases: CINAHL, ScienceDirect, Scopus, Web of Science, ProQuest, and the Cochrane Database of Systematic Reviews. In addition, the "gray" literature was searched using Mednar with only the first 500 results reviewed. Search terms for all databases included the following: (climate change OR greenhouse) AND (emissions OR carbon) AND (diet* OR food OR meat OR livestock OR vegetarian OR agriculture OR nutrition). The searched fields were keyword, title, and abstract where available. Searches were limited to English language studies and to publications from January 1995 to July 2014. Studies were included if they were primary research studies modeling GHG emissions associated with a dietary pattern using life-cycle analysis or similar methods. Studies were excluded if the modeling focused only on specific food types (rather than on a realistic dietary scenario), energy input, food miles, or a specific agricultural practice.

All citations were downloaded into EndNote software. Titles (and then abstracts where available) were screened for relevance to diet and the environment. Citations were categorized into two groups: 1) possibly relevant studies and 2) excluded studies (studies not related to diet and climate). The full text of all candidate studies (ie, possibly relevant studies) was obtained, using a low threshold for inclusion if there was any doubt. These publications were then screened against the inclusion criteria to determine eligibility. A standard data-recording form was used to extract information from each included study. The data extracted included the following: 1) geographical location of the study, 2) dietary patterns included in the modeling, 3 ) outcomes (units of measurement and process used), and 4) study findings.

\section{Dietary impacts on GHG emissions}

Figure 1 outlines the selection process. The search process identified 13,855 articles from the seven sources, leaving 8,669 after duplicates had been removed. After the titles were screened for relevance (excluding studies not on diet and climate; $n=8,370), 299$ articles remained. Screening of the abstracts resulted in 116 articles appearing relevant. A further 95 articles were excluded after full-text review found that they did not report on relevant outcomes and therefore did not meet the inclusion criteria. Thus, 21 articles were included in this paper, and a summary of their characteristics and findings is provided in Table $1 .^{8,12-31}$ Owing to the marked heterogeneity of the study designs and underlying assumptions, we conducted a qualitative review, focusing on describing the studies and their findings, rather than a meta-analysis.

The included studies were predominantly European, with one each from Australia, ${ }^{15}$ New Zealand, ${ }^{30}$ North America, ${ }^{25}$ and India. ${ }^{20}$ All studies used an average diet based on food surveys of the population as a comparison reference to additional diet scenarios. All studies included diets based on reducing meat consumption, with eleven studies including at least one diet lacking meat (vegetarian or vegan) $8,12,18-22,24,25,27,30$ and eight studies including a diet that excluded all animal food products (vegan). ${ }^{8,18,20-22,24,27,30}$ Additional variations included comparisons with local recommended dietary guidelines, all of which contained less meat than the average diet for the population. ${ }^{14,15,18,19,21-23,26,27}$ Four studies included a Mediterranean diet, ${ }^{19,26,27,30}$ which is "based more on cereals, vegetables, fruit and fish than on potatoes, meat and dairy foods, eggs and sweets." 19 


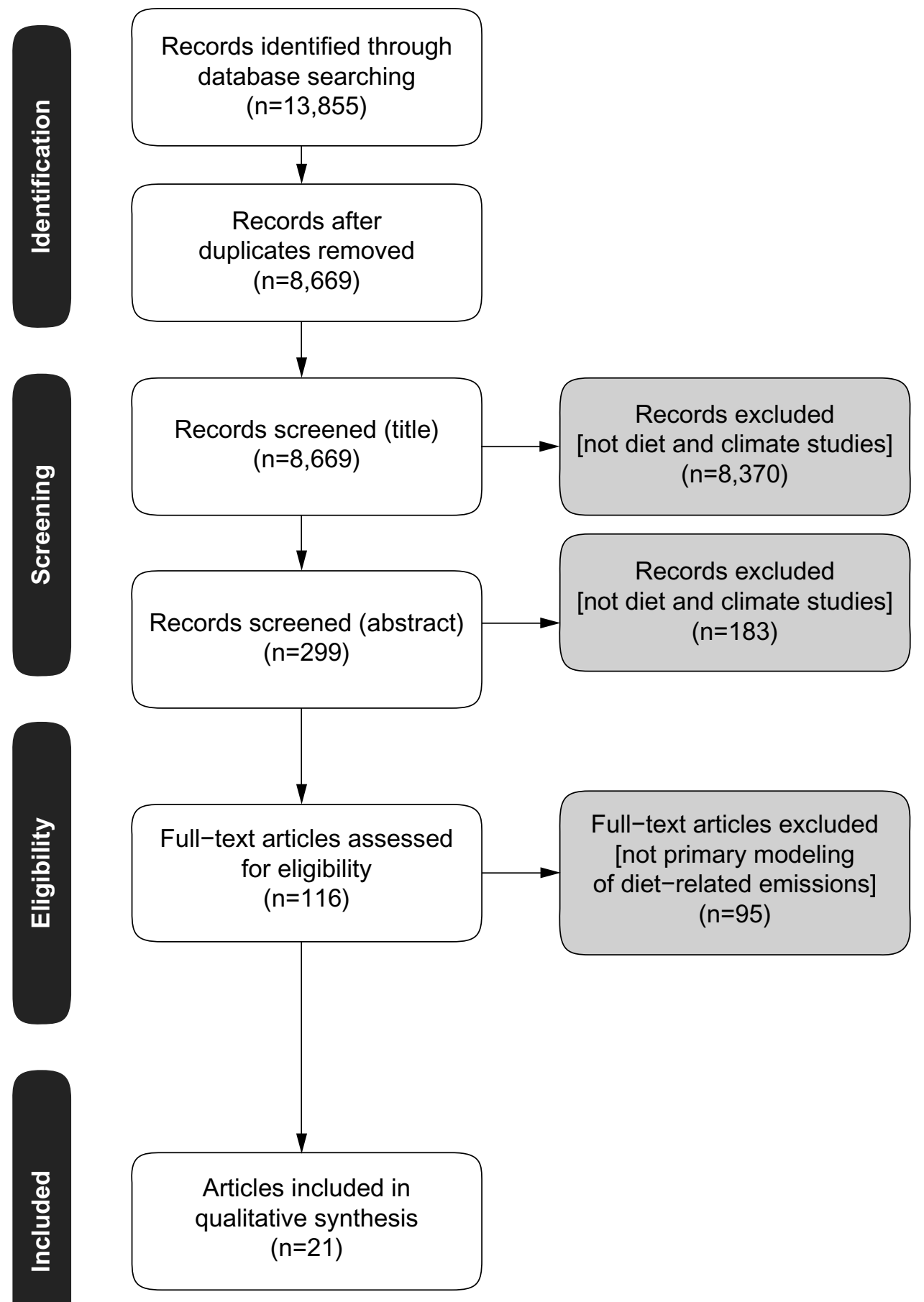

Figure I Study selection.

Most studies used a form of life-cycle assessment (LCA), with several including input-output analysis. LCA is an internationally accepted method that enables industries to identify the inputs (such as resources, electricity, and water) and outputs (such as GHG emissions and waste) associated with the provision of products. ${ }^{32}$ LCA is widely used in the agricultural sector to evaluate the environmental impacts associated with a product or process over its entire life cycle. Through extensive data collection on all stages of the process, LCA provides a systematic method of quantifying the amount of global warming potential or GHG equivalents (as units of carbon dioxide) emitted over the whole life cycle of a 
Table I Study characteristics

\begin{tabular}{|c|c|c|c|c|}
\hline Study & $\begin{array}{l}\text { Location/ } \\
\text { geographic focus }\end{array}$ & Diets studied $^{a}$ & $\begin{array}{l}\text { Study method and } \\
\text { outcome measure }\end{array}$ & Study finding \\
\hline Aston et $\mathrm{al}^{12}$ & UK & $\begin{array}{l}\text { Six average diets (stratified by } \\
\text { energy-adjusted red and processed } \\
\text { meat consumption levels, including } \\
\text { one vegetarian) }\end{array}$ & $\begin{array}{l}\mathrm{LCA} \\
\mathrm{CO}_{2} \mathrm{e} \mathrm{GHG}\end{array}$ & $\begin{array}{l}\text { Lower red or processed meat } \\
\text { consumption lowered GHG emissions }\end{array}$ \\
\hline $\begin{array}{l}\text { Berners-Lee } \\
\text { et } \mathrm{al}^{8}\end{array}$ & UK & $\begin{array}{l}\text { Six dietary scenarios (three vegetarian } \\
\text { and three vegan, with different meat } \\
\text { and dairy substitutions applied) } \\
\text { compared with the average diet }\end{array}$ & $\begin{array}{l}\mathrm{LCA} \\
\mathrm{CO}_{2} \mathrm{e} \mathrm{GHG}\end{array}$ & $\begin{array}{l}\text { Potential GHG savings of } 22 \% \text { and } \\
26 \% \text { can be made by changing from the } \\
\text { current UK-average diet to a vegetarian } \\
\text { and a vegan diet, respectively }\end{array}$ \\
\hline Geeraert $^{13}$ & Sweden & Average diets between 1960 and 2006 & $\begin{array}{l}\mathrm{LCA} \\
\mathrm{CO}_{2} \mathrm{e} \mathrm{GHG}\end{array}$ & $\begin{array}{l}\text { An increase in average meat consumption } \\
\text { from } 1960 \text { to } 2006 \text { has resulted in a } 60 \% \\
\text { increase in GHG emissions }\end{array}$ \\
\hline $\begin{array}{l}\text { Hallström } \\
\text { et al }{ }^{14}\end{array}$ & Sweden & $\begin{array}{l}\text { Average diet, dietary guidelines model I } \\
\text { (reduced meat consumption), dietary } \\
\text { guidelines model } 2 \text { (reduced meat } \\
\text { consumption from resource-efficient } \\
\text { systems) }\end{array}$ & $\begin{array}{l}\mathrm{LCA} \\
\mathrm{CO}_{2} \mathrm{e} \mathrm{GHG}\end{array}$ & $\begin{array}{l}\text { Reductions in meat consumption would } \\
\text { cut GHG emissions by } 40 \%-70 \%\end{array}$ \\
\hline $\begin{array}{l}\text { Hendrie } \\
\text { et } \mathrm{al}^{15}\end{array}$ & Australia & $\begin{array}{l}\text { Average diet, average diet with minimal } \\
\text { noncore foods, a "total diet" (dietary } \\
\text { recommendations including some noncore } \\
\text { foods), "foundation diet" (dietary guidelines } \\
\text { excluding noncore foods) }\end{array}$ & $\begin{array}{l}\mathrm{IO} \\
\mathrm{CO}_{2} \mathrm{e} \mathrm{GHG}\end{array}$ & $\begin{array}{l}\text { The foundation diet had the lowest } \\
\text { GHG emissions ( } 25 \% \text { lower than the } \\
\text { average diet). Red meat and noncore } \\
\text { foods made the greatest contribution to } \\
\text { diet-related GHG emissions }\end{array}$ \\
\hline $\begin{array}{l}\text { Hoolohan } \\
\text { et } \mathrm{al}^{31}\end{array}$ & UK & $\begin{array}{l}\text { Average diet and decreased meat } \\
\text { consumption at } 5 \% \text { increments }\end{array}$ & $\begin{array}{l}\mathrm{LCA} \\
\mathrm{CO}_{2} \mathrm{e} \mathrm{GHG}\end{array}$ & $\begin{array}{l}\text { Eliminating meat consumption results in } \\
\text { a } 35 \% \mathrm{GHG} \text { emissions saving }\end{array}$ \\
\hline $\begin{array}{l}\text { Macdiarmid } \\
\text { et } \text { al }^{16}\end{array}$ & UK & $\begin{array}{l}\text { Average diet compared with a "sustainable } \\
\text { diet" (dietary guidelines but with reduced } \\
\text { GHG-intensive foods, including } 40 \% \\
\text { reduced meat consumption) }\end{array}$ & $\begin{array}{l}\text { LCA and linear } \\
\text { programming } \\
\mathrm{CO}_{2} \text { e GHG }\end{array}$ & $\begin{array}{l}\text { Reductions in GHG emissions can be } \\
\text { achieved by lowering meat consumption; } \\
\text { this diet meets dietary guidelines and } \\
\text { does not increase the cost or eliminate } \\
\text { meat or dairy products }\end{array}$ \\
\hline $\begin{array}{l}\text { Masset } \\
\text { et } \text { al }^{17}\end{array}$ & France & $\begin{array}{l}\text { Average diet, "lower-carbon" diet } \\
\text { (total diet-related GHG emissions lower } \\
\text { than the median), "higher quality" diet } \\
\text { (PANDiet index score higher than the } \\
\text { median), "more sustainable" (low-carbon } \\
\text { and high-quality) diets }\end{array}$ & $\begin{array}{l}\mathrm{LCA} \\
\mathrm{CO}_{2} \mathrm{e} \mathrm{GHG}\end{array}$ & $\begin{array}{l}\text { A } 20 \% \text { reduction in diet-related GHG } \\
\text { emissions, while maintaining high } \\
\text { nutritional quality, is possible at no } \\
\text { extra cost by reducing energy intake } \\
\text { and energy density and increasing the } \\
\text { share of plant-based products }\end{array}$ \\
\hline $\begin{array}{l}\text { Meier and } \\
\text { Christen }\end{array}$ & Germany & $\begin{array}{l}\text { Average diet, two food-based dietary } \\
\text { guidelines (D-A-CH; UGB), lacto-ovo } \\
\text { vegetarian, vegan }\end{array}$ & $\begin{array}{l}\text { Hybrid LCA-IO } \\
\mathrm{CO}_{2} \text { emissions }\end{array}$ & $\begin{array}{l}\text { The greatest impact on } \mathrm{CO}_{2} \text { emissions } \\
\text { was from a vegan diet, followed by a } \\
\text { lacto-ovo vegetarian diet }\end{array}$ \\
\hline $\begin{array}{l}\text { Pairotti } \\
\text { et al }{ }^{19}\end{array}$ & Italy & $\begin{array}{l}\text { Average diet, Mediterranean diet, healthy } \\
\text { diet (dietary guidelines), vegetarian }\end{array}$ & $\begin{array}{l}\text { Hybrid LCA-IO } \\
\mathrm{CO}_{2} \text { e GHG }\end{array}$ & $\begin{array}{l}\text { The vegetarian diet was the cheapest } \\
\text { and had the lowest carbon footprint, } \\
\text { followed by the Mediterranean diet } \\
\text { (owing to reduced animal products) }\end{array}$ \\
\hline $\begin{array}{l}\text { Pathak } \\
\text { et } \mathrm{al}^{20}\end{array}$ & India & $\begin{array}{l}\text { Balanced diet, vegan, lacto vegetarian, } \\
\text { ovo vegetarian (vegetarian with egg), } \\
\text { nonvegetarian with poultry meat, } \\
\text { nonvegetarian with mutton }\end{array}$ & $\begin{array}{l}\text { Varied GWP } \\
\mathrm{CO}_{2} \mathrm{e} \mathrm{GHG}\end{array}$ & $\begin{array}{l}\text { Diets based on crop food products had } \\
\text { lower GHG emissions than those based } \\
\text { on animal foods. Ruminant sources } \\
\text { contributed more emissions than poultry }\end{array}$ \\
\hline $\begin{array}{l}\text { Risku-Norja } \\
\text { et } \mathrm{al}^{22}\end{array}$ & Finland & $\begin{array}{l}\text { Average diet, dietary guidelines, diet with } \\
\text { no dairy or ruminants (but including pork } \\
\text { and poultry), vegan }\end{array}$ & $\begin{array}{l}\mathrm{LCA} \\
\mathrm{CO}_{2} \text { e GHG }\end{array}$ & $\begin{array}{l}\text { All options reduced GHG emissions } \\
\text { compared with the average diet, with } \\
\text { the vegan diet almost halving emissions }\end{array}$ \\
\hline
\end{tabular}


Table I (Continued)

\begin{tabular}{|c|c|c|c|c|}
\hline Study & $\begin{array}{l}\text { Location/ } \\
\text { geographic focus }\end{array}$ & Diets studied $^{a}$ & $\begin{array}{l}\text { Study method and } \\
\text { outcome measure }\end{array}$ & Study finding \\
\hline $\begin{array}{l}\text { Risku-Norja } \\
\text { et al }{ }^{21}\end{array}$ & Finland & $\begin{array}{l}\text { Organic and conventional options of } \\
\text { average diet, dietary guidelines, mixed } \\
\text { diet with no pork or poultry, vegan }\end{array}$ & $\begin{array}{l}\mathrm{EIA} \\
\mathrm{CO}_{2} \mathrm{e} \mathrm{GHG}\end{array}$ & $\begin{array}{l}\text { The vegetarian diet was associated } \\
\text { with lower emissions but reduced crop } \\
\text { diversity. Organic options had higher } \\
\text { GHG emissions }\end{array}$ \\
\hline Saxe et $\mathrm{a}^{23}$ & Denmark & $\begin{array}{l}\text { Average diet, dietary guidelines, } \\
\text { alternative dietary guidelines } \\
(>75 \% \text { organically produced) }\end{array}$ & $\begin{array}{l}\mathrm{LCA} \\
\mathrm{CO}_{2} \mathrm{e} \mathrm{GHG}\end{array}$ & $\begin{array}{l}\text { Dietary guideline diets had lower GHG } \\
\text { emissions, although the difference } \\
\text { was reduced with increases in organic } \\
\text { produce }\end{array}$ \\
\hline $\begin{array}{l}\text { Scarborough } \\
\text { et al }{ }^{24}\end{array}$ & UK & $\begin{array}{l}\text { Dietary reports from self-selected meat } \\
\text { eaters, fish eaters, vegetarians, vegans }\end{array}$ & $\begin{array}{l}\text { LCA, GWP } \\
\mathrm{CO}_{2} \text { e GHG }\end{array}$ & $\begin{array}{l}\text { Dietary GHG emissions in self-selected } \\
\text { meat eaters were about twice as high } \\
\text { as in vegans }\end{array}$ \\
\hline Soret et $\mathrm{a}^{25}$ & North America & $\begin{array}{l}\text { Vegetarian, semi-vegetarian (meat consumed } \\
\text { more than once per month but less than } \\
\text { once per week), nonvegetarian }\end{array}$ & $\begin{array}{l}\mathrm{LCA} \\
\mathrm{CO}_{2} \mathrm{e} \mathrm{GHG}\end{array}$ & $\begin{array}{l}\text { Vegetarians and semi-vegetarians } \\
\text { contributed almost one-third and more } \\
\text { than one-fifth less GHG emissions, } \\
\text { respectively, than nonvegetarians }\end{array}$ \\
\hline $\begin{array}{l}\text { Tukker } \\
\text { et } \mathrm{al}^{26}\end{array}$ & Europe & $\begin{array}{l}\text { Average diet, dietary guidelines, dietary } \\
\text { guidelines with reduced meat consumption, } \\
\text { "Mediterranean" pattern with reduced } \\
\text { meat consumption }\end{array}$ & $\begin{array}{l}\text { Hybrid LCA-IO } \\
\mathrm{CO}_{2} \text { e GHG }\end{array}$ & $\begin{array}{l}\text { Reductions in GHG emissions were } \\
\text { seen in the reduced meat scenarios }\end{array}$ \\
\hline $\begin{array}{l}\text { van Dooren } \\
\text { et } \mathrm{al}^{27}\end{array}$ & The Netherlands & $\begin{array}{l}\text { Average diet, dietary guidelines, } \\
\text { semi-vegetarian, vegetarian, vegan, } \\
\text { Mediterranean }\end{array}$ & $\begin{array}{l}\mathrm{LCA} \\
\mathrm{CO}_{2} \text { e GHG }\end{array}$ & $\begin{array}{l}\text { Non-average diets reduced emissions } \\
\text { by at least } 20 \% \text {, and higher for the } \\
\text { vegan diet }\end{array}$ \\
\hline Vieux et a $\left.\right|^{28}$ & France & $\begin{array}{l}\text { Average diet, scenario I ( } 20 \% \text { meat } \\
\text { and/or deli meat reduction), scenario } 2 \\
\text { (meat reduction to } 50 \mathrm{~g} / \text { day maximum } \\
\text { and no deli meat) }\end{array}$ & $\begin{array}{l}\text { Monte-Carlo } \\
\text { simulation } \\
\mathrm{CO}_{2} \text { e GHG }\end{array}$ & $\begin{array}{l}\text { When replacing meat with fruit and } \\
\text { vegetables, which are less energy dense, } \\
\text { GHG emissions increased }\end{array}$ \\
\hline 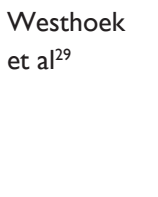 & Europe & $\begin{array}{l}\text { Average diet; reduction of } 50 \% \text { in beef } \\
\text { and dairy consumption; reduction of } 50 \% \\
\text { in pig meat, poultry, and egg consumption; } \\
\text { reduction of } 50 \% \text { in all meat, dairy, } \\
\text { and egg consumption }\end{array}$ & $\begin{array}{l}\text { MITERRA-EUROPE } \\
\mathrm{CO}_{2} \text { e GHG }\end{array}$ & $\begin{array}{l}\text { Halving the consumption of meat, dairy } \\
\text { products, and eggs would achieve a } \\
25 \%-40 \% \text { reduction in GHG emissions }\end{array}$ \\
\hline $\begin{array}{l}\text { Wilson } \\
\text { et } \mathrm{al}^{30}\end{array}$ & New Zealand & $\begin{array}{l}\text { Average male diet; four modified average } \\
\text { diets; four low-cost diets; four low-GHG } \\
\text { and low-cost diets, including vegan; } \\
\text { four "relatively healthy diets", with high } \\
\text { vegetable intakes (Mediterranean and Asian } \\
\text { style diets, with a low GHG alternative) }\end{array}$ & $\begin{array}{l}\mathrm{LCA} \\
\mathrm{CO}_{2} \mathrm{e} \mathrm{GHG}\end{array}$ & $\begin{array}{l}\text { The vegan diet resulted in slightly } \\
\text { higher GHG emissions and was more } \\
\text { expensive than the other "low-GHG } \\
\text { diets" }\end{array}$ \\
\hline
\end{tabular}

Notes: a"Average diet" refers to population level dietary surveys. "Dietary guidelines" refers to national recommendations or those developed by relevant nutritional associations. "Noncore foods were defined as nonessential, energy-dense processed foods. "Monte-Carlo simulation considered LCA only up to the time of purchase. MITERRA-EUROPE assessed the possible effects of nitrogen abatement measures on emissions and leaching of nitrogen into ground and surface waters.

Abbreviations: $\mathrm{CO}_{2} \mathrm{e}$, carbon dioxide equivalents; EIA, environment impact assessment; GHG, greenhouse gas; GWP, global warming potential; IO, input-output; LCA, life-cycle assessment; D-A-CH, official recommendations of German Nutrition Society; UGB, alternative recommendations by Federation for Independent Health Consultation.

product. ${ }^{32}$ A comparison of quantitative changes in emissions between studies was complicated by not only the different metrics used to quantify GHGs but also the different components included in the estimations and the normalization of energy content between different diet scenarios. Most studies that quantified the difference in GHG emissions between average or typical and nonmeat diets reported their findings in kilograms, tonnes, or megatonnes of carbon dioxide equivalents $\left(\mathrm{CO}_{2} \mathrm{e}\right)$, either per person or nationally, and either per day or per year. 
The study by Hoolohan et $\mathrm{al}^{31}$ reported the highest GHG values for both types of diet; however, their modeling included emissions from waste, packaging, freight, and hot housing as well as primary production. Starting with a baseline UK diet $(3,458 \mathrm{kcal})$ that resulted in emissions of $3.21 \mathrm{t}$ $\mathrm{CO}_{2}$ e person ${ }^{-1}$ year $^{-1}\left(8.81 \mathrm{~kg} \mathrm{CO}_{2}\right.$ e person ${ }^{-1}$ day $\left.^{-1}\right)$, they found that eliminating meat would result in a $35 \%$ saving in GHG emissions down to $2.10 \mathrm{t} \mathrm{CO}_{2}$ e person ${ }^{-1}$ year $^{-1}(5.76 \mathrm{~kg}$ $\mathrm{CO}_{2}$ e person ${ }^{-1}$ day $\left.^{-1}\right)$. These levels, both with and without meat, are significantly greater than those reported by other studies in this report including Risku-Norja et a ${ }^{22}$ who only considered emissions from primary production. The authors in this study found that the typical meat-containing Finnish diet resulted in GHG emissions of 1,692 $\mathrm{kg}(1.692 \mathrm{t}) \mathrm{CO}_{2} \mathrm{e}$ person $^{-1}$ year $^{-1}$ compared to a typical vegetarian diet that resulted in only $879 \mathrm{~kg}(0.879 \mathrm{t}) \mathrm{CO}_{2}$ e person ${ }^{-1}$ year $^{-1}$. This equated to a $48 \%$ saving of $0.813{\text { t } \mathrm{CO}_{2} \text { e person }}^{-1}$ year $^{-1}$.

Berners-Lee et $\mathrm{al}^{8}$ calculated the GHG emissions of the current UK food supply to be $7.4 \mathrm{~kg} \mathrm{CO}_{2}$ e person ${ }^{-1}$ day $^{-1}$ or $2.7 \mathrm{t} \mathrm{CO}_{2}$ e person ${ }^{-1}$ year $^{-1}$. This was calculated on food as purchased, including wastage and food loss and based on a normalized energy content of 3,458 $\mathrm{kcal} \mathrm{day}^{-1}$. Comparing this with estimated GHG emissions from several vegetarian diet scenarios, they found potential decreases of between $22 \%$ and $26 \%$, which equate to approximately $1.78 \mathrm{~kg} \mathrm{CO}_{2} \mathrm{e}$ person $^{-1}$ day $^{-1}$ or $0.65 \mathrm{t} \mathrm{CO}_{2}$ e person ${ }^{-1}$ year $^{-1}$. The authors also estimated a national saving for the UK of $40 \mathrm{Mt} \mathrm{CO}_{2} \mathrm{e}$ year ${ }^{-1}$. Meier and Christen ${ }^{18}$ reported GHG emissions from a typical German diet for males and females as $2.13 \mathrm{t} \mathrm{CO}_{2} \mathrm{e}$ person $^{-1}$ year $^{-1}$ and $1.98 \mathrm{t} \mathrm{CO}_{2}$ e person ${ }^{-1}$ year $^{-1}$, respectively, which decreased to $0.96 \mathrm{t} \mathrm{CO}_{2} \mathrm{e}$ person ${ }^{-1}$ year $^{-1}$ and $1.56 \mathrm{t}$ $\mathrm{CO}_{2}$ e person ${ }^{-1}$ year $^{-1}$ for vegan and lacto-ovo vegetarian diets, respectively. These figures were based on a normalized 2,000 kcal diet, which is considerably lower than the kcal allowance in the typical UK diet; however, after allowing for food loss and wastage, only 2,259 kcal was actually consumed. van Dooren et $\mathrm{al}^{27}$ also took sex into consideration and estimated GHG emissions for the average diet for Dutch adult females to be $4.09 \mathrm{~kg} \mathrm{CO}_{2}$ e person ${ }^{-1}$ day $^{-1}\left(1.49 \mathrm{t} \mathrm{CO}_{2} \mathrm{e}\right.$ person $^{-1}$ year $\left.^{-1}\right)$. This reduced by at least $20 \%$ for vegetarian diets to $3.2 \mathrm{~kg} \mathrm{CO}_{2}$ e person ${ }^{-1}$ day $^{-1}\left(1.17 \mathrm{t} \mathrm{CO}_{2}\right.$ e per$\mathrm{son}^{-1}$ year $\left.^{-1}\right)$ and even more for vegan diets to $2.65 \mathrm{~kg} \mathrm{CO}_{2} \mathrm{e}$ person $^{-1}$ day $^{-1}\left(1.17\right.$ t CO $_{2}$ e person ${ }^{-1}$ year $\left.^{-1}\right)$.

Studies from other countries reported substantially lower diet-related emissions, possibly due to reduced meat content in the diet. Pathak et $\mathrm{al}^{20}$ used a typical Indian vegetarian diet as their baseline and reported on the increases in potential GHG emissions based on the type of meat introduced into the diet. They found emissions from male vegetarian diets to

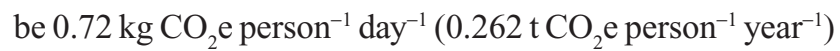
and female diets $0.58 \mathrm{~kg} \mathrm{CO}_{2}$ e person ${ }^{-1}$ day $^{-1}\left(0.211 \mathrm{t} \mathrm{CO}_{2} \mathrm{e}\right.$ person $^{-1}$ year $\left.^{-1}\right)$. They found this increased 1.8 times when mutton was included in the diet, 1.5 times with chicken, and 1.4 times with ovo-lacto vegetarian diets.

All but two studies ${ }^{28,30}$ found that the greater the reduction in animal-based foods, the greater the GHG emission reduction. These studies differed from other studies that matched diets on the basis of overall energy levels, giving consideration to ensuring adequate nutrition levels for each diet. ${ }^{8,33}$ By contrast, Vieux et al ${ }^{28}$ matched diets on the basis of the calories needed to replace a $20 \%$ meat reduction. Wilson et $\mathrm{al}^{30}$ matched diets according to nutrient levels and found that replacements for eggs and dairy were more costly economically and had greater GHG emissions for the equivalent nutrient levels.

Most studies found that diets containing less meat resulted in significantly reduced emissions in the primary phase of food production, with two studies ${ }^{22,24}$ finding that a vegan diet contributed approximately one-half of the GHG emissions of the typical average food consumption. According to Raphaely and Marinova, ${ }^{33}$ estimates from various sources indicate that a $25 \%$ reduction in global meat consumption would translate into a $12.5 \%$ reduction in global anthropogenic GHG emissions. Some authors concluded that the widespread adoption of a healthier diet, with small or even no reductions in meat consumption, could both improve population health and reduce carbon emissions. ${ }^{15,16}$

Four of the excluded studies explored modeling agricultural changes on a global scale with scenarios of varied levels of meat and dairy consumption. ${ }^{34-37}$ Scenarios with reduced animal food production had greater potential to reduce GHG emissions than did technological mitigation or increased productivity measures, ${ }^{34,35}$ with the highest GHG reduction potential achieved by a combination. ${ }^{35}$ The high calorie diets in the developed world resulted in high total per capita GHG emissions compared to the lower calorie diets elsewhere, owing to high carbon intensity and high intake of animal-based products. ${ }^{36} \mathrm{~A}$ global transition to eating less meat or completely switching to plant-based protein food was estimated to also have a marked effect on land use and clearing. ${ }^{37}$ Research that models future scenarios has also shown that current consumption trends are unsustainable and that reduction in livestock needs to be part of the solution to ensure future food security. ${ }^{38}$ The research reviewed in this paper is also consistent with research modeling the specific contribution of different food types with a recent study 
concluding that beef has a much greater GHG impact relative to other types of animal products and vegetable products. ${ }^{39}$ The work of Eshel et $\mathrm{al}^{39}$ underscores the importance of developing methodologies that facilitate comparison between food types and choices, which is currently difficult from the diet-modeling research.

\section{Health implications}

Initiatives to reduce the consumption of animal-based foods in favor of plant-based foods may not have the goal of increasing the proportion of the population that consumes a vegetarian or vegan diet, but this may be a consequence of such an approach. Thus, the health implications need to be carefully considered. A diverse range of eating patterns is associated with plant-based diets. A generic definition of a vegetarian diet is a "dietary pattern that is characterized by the consumption of plant foods and the avoidance of some or all animal products. ${ }^{40}$ Vegan diets exclude all animal products, including dairy products. ${ }^{41}$

Vegetarian diets can be used to meet the nutritional requirements at all stages of life, including pregnancy, lactation, childhood, and adolescence. ${ }^{42,43}$ According to the American Dietetic Association ${ }^{41}$ (now the Academy of Nutrition and Dietetics), in well-planned vegetarian diets, the levels of protein, iron, zinc, calcium, vitamin D, riboflavin, vitamin B12, omega-3 fatty acids, and iodine meet nutritional requirements. In addition to being nutritionally adequate, a vegetarian diet has been shown to provide positive health benefits, aiding in disease prevention. ${ }^{41}$ Another aspect of a plant-based diet is a higher consumption of antioxidants, flavonoids, and phytochemicals, which have key roles in preventing cardiovascular disease. ${ }^{44} \mathrm{~A}$ diet that is high in plant-based foods has also been linked to a decreased risk of cardiovascular disease, type 2 diabetes, and certain cancers. ${ }^{45}$ Vegetarians who limit their intake of milk and other dairy products may also have a reduced risk of developing certain chronic diseases, given that many dairy products contain saturated fat and cholesterol. Humans do not need milk after they have been weaned and because the nutrients in milk are readily available in foods without animal protein. ${ }^{46}$ Overall, therefore, well-considered vegetarian or vegan diets seem to offer health benefits, particularly in relation to chronic disease.

Where there is risk from a public health perspective, it is in how these messages are interpreted and acted on that needs to be carefully considered. Higher rates of eating-disordertype behaviors have been found among teenagers and women in their twenties who describe themselves as semi-vegetarian or vegetarian; however, this relationship was less evident in young people motivated by ethical concerns. ${ }^{40,47,48}$ It is possible that among certain groups, a communication strategy that encourages reducing the consumption of certain food types may contribute to a rise in eating-disorder-type behaviors; thus, a safer approach for young people could be focusing on increasing the consumption of certain food types. For example, obesity prevention programs have been found to promote the uptake of eating disorder behaviors among adolescents. ${ }^{49}$ How messages can be framed to promote positive health behaviors needs further research.

\section{Policy implications}

Given the majority of the research reviewed concluded that higher consumption of animal products was linked to higher GHG emissions, reductions in government subsidies of animal-sourced foods would seem to be a rational policy approach. Popkin ${ }^{50}$ recommended the removal of subsidies for animal-sourced foods that have distorted food prices in the USA, Europe, and other developed countries, and investments in healthier plant-based foods. These recommendations are supported by other researchers, ${ }^{41,42}$ but as yet these suggestions have not been presented in the context of existing knowledge of political agenda setting or policy. ${ }^{51}$ Of particular relevance to this issue is the growing body of research on policy networks. This approach views policymaking and policy implementation as taking place within, and being influenced by, networks. These networks consist of individuals, coalitions, and organizations. ${ }^{52}$ From this perspective, policymaking is viewed as cooperation or noncooperation between interdependent groups with different interests, ideologies, and strategies. ${ }^{52}$ Understanding the processes through which different actors shape and reshape political agendas and policy decisions can help to reveal barriers to government action on sustainable nutrition. Based on this understanding, more specific recommendations to promote government action can be made, not only about which actions are needed by nongovernment organizations but also about how these actions could be brought about.

Governments have several "policy instruments", or tools, at their disposal for encouraging changes in sustainable food consumption. Policy instruments refer to the techniques the government has at its disposal to either ensure support or prevent change in a particular area. Broadly, these include the following: regulations, in which formal rules and directives are used; economic incentives or disincentives, in which individuals are not obliged to perform an action, but the actions are made easier or more difficult by the addition or 
deprivation of material resources; and information-oriented tools, in which governments seek to persuade citizens through claims and reasoning. ${ }^{53}$ These instruments can be viewed as existing on a continuum of authoritative force (ie, from legislation being the most forceful and persuasion being the least). The reviewed literature makes general references to these options for action by government; ${ }^{15,35}$ however, there is a lack of discussion or specificity about which of these tools might work best in the context of sustainable nutrition or which might be politically viable. The challenge for future research is therefore to explore how to promote cooperation between health and environmental organizations to enable policy change.

Several authors recommended that encouraging the adoption of healthy diets could improve both population health and reduce carbon emissions. ${ }^{15,16}$ This idea has the intuitive appeal of linking health and environmental groups to advocate for policy change. ${ }^{52}$ However, the literature on obesity prevention suggests that population messages around healthy eating are ineffectual. ${ }^{55}$ One theorist has recommended using social movements to motivate behavioral change to reduce the population levels of obesity. ${ }^{55}$ For example, causes that have a strong emotional pull and that share goals with obesity prevention, such as social justice, animal rights, or environmental sustainability, could be supported, rather than attempting to use messages that focus on rational arguments about health benefits, given that this approach has yielded little long-term population change. ${ }^{55}$ The challenge for framing dietary change around a more emotive topic is gaining the consensus that is required to form a policy "coalition". Health may prove politically to be a more acceptable message than the environment or animal rights. Pairotti et al, ${ }^{19}$ for example, recommend championing the Mediterranean diet as a compromise rather than a vegetarian or vegan diet because of the cultural value of meat in Italian society. However, although a health message may be easier to sell politically, it may result in policies and programs that do not shift dietary behavior.

Research has emerged that suggests that the public may be more receptive than expected to messages about the need for policy changes in relation to meat reduction. Dagevos and Voordouw ${ }^{56}$ conducted an online survey in $2009(n=800)$ and $2011(n=1,253)$, with participants being representative of Dutch population norms with respect to sex, age, and education level. The survey questions focused on frequency of eating meat, attitudes toward meat, and motives for consuming more or less meat. In 2009, 26.7\% of the sample ate meat every day, and this figure dropped to $18.4 \%$ in 2011 .
The most common response in both study periods was eating meat five or six times per week, followed by three or four times per week. The authors also conducted a cluster analysis according to meat-eating frequency, and they found that in meat eaters, subgroups occasionally emerged with respect to sex, education level, age, and motivations. For example, women with higher levels of education were more likely to be motivated by ethics and health and made conscious decisions to reduce their meat intake. Other identified subgroups were not actively conscious of reducing meat intake but were motivated by social norms or price. The authors concluded that this heterogeneity in meat consumption and attitudes is in contrast to popular conceptions that meat consumption patterns are not malleable. ${ }^{56}$

In this way, this study found potential opportunities for targeted communication strategies aimed at reducing meat consumption, without the need for endorsing vegetarian diets. The authors concluded that raising awareness of the need to reduce meat consumption would have a receptive audience and is a necessary starting point for increasing public acceptance of more effective strategies, such as market-based and regulatory policies. Similarly, a study of Finnish university students found that the feasibility of adopting a vegetarian diet was high; however, the importance of this behavior was ranked low. ${ }^{54}$ Although it cannot be assumed that such findings would translate to other cultural groups, there are, nonetheless, important implications for research and policy.

One implication of this heterogeneity in meat eating and motivation to change is that people who have a healthy diet already (educated females, for instance) are more likely to respond to messages around reducing meat consumption. Thus, a population reduction in meat consumption may not realize population gains in health. There is also a risk that such messages will lead adolescents to adopt eating disorder behaviors, which has occurred in obesity prevention programs. ${ }^{13}$ Thus, although dietary modeling behaviors have shown that population gains in health and sustainability can be achieved with reductions in meat, ${ }^{57}$ it is more likely that different groups will take up the messages in different ways, and it cannot be assumed that policies and programs aimed at reducing meat and dairy consumption will have positive effects for population health. Again, this suggests that there will be challenges in finding a consensus on how to frame this issue for broader public and political support.

Reducing meat and dairy consumption as a means to reduce GHG emissions must also be considered in the context of economic affordability and overall patterns of consumption. Populations in developed counties are more 
likely to be able to afford alternative protein sources than those in developing counties, where a low-meat diet presents nutritional challenges and there is already undernourishment and malnourishment. For $70 \%$ of the world's "extremely poor", rearing animals is an important part of their lives, and animal sources of food can make a considerable difference to the quality of their diet. ${ }^{58}$ Both in developing countries and in developed countries, research has found that the cost of healthy foods is more expensive.

An Australian study compared the cost of a "healthy and environmentally sustainable food basket" and a typical basket of food for a family of two adults and two children. ${ }^{59}$ Results were compared across five neighborhoods and it was discovered that the greatest percentage difference between the two types of food baskets was in the most economically disadvantaged neighborhood. Those in the lowest income quintile across the five neighborhoods would have to spend between $40 \%$ and $48 \%$ of their income to buy the healthy basket. Similarly, a study conducted in South Africa found that healthier diets are more expensive and unaffordable for the majority of the population. ${ }^{60}$ Its analysis was based on substituting healthier options of the same types of food (eg, a lean hamburger compared to a hamburger high in fat).

Of the diet-modeling studies reviewed in this paper, Pairotti et a ${ }^{19}$ found that the healthy option was the most expensive; the Mediterranean diet was similar to the average and the vegetarian diet was cheaper than the average. In the Macdiarmid et $\mathrm{a}^{16}$ study, the cost of the healthy diet was comparable to current food expenditure. Implementing this style of change would require a knowledgeable and motivated population, a population that Temple and Steyn doubt exists. ${ }^{60}$ In their analysis, even when different foods were substituted that were lower in cost (eg, lentils rather than hamburgers), these lower cost healthier options were still too expensive for the majority of the population. They concluded that community education strategies will be ineffective unless there are taxation and subsidy interventions to change food prices. The challenge then is to find policy options and community support for such options that potentially yield health and environmental gains without increasing food costs and ideally, improving access to healthy food.

\section{Conclusion}

Diet-modeling research has provided several options for reducing GHG emissions. Some researchers advocate a health approach, some advocate combining a health and environmental approach, and others focus on reducing meat consumption, while acknowledging that this will provide health benefits. There is considerable heterogeneity in dietary behavior and in motivations to change; ${ }^{61}$ thus, it cannot be assumed at this stage that focusing on a health or environmental campaign alone will effect change across both domains. Further research on community attitudes toward dietary change, health, and environment is required.

Several studies have suggested options for policies and programs by which governments can restructure food industry subsidies to reduce GHG emissions. However, the challenge in this research is finding a position of compromise around which to galvanize a coalition of support for policy change among health and environmental organizations. Further research is required on how the issues can be framed to engage the general public, which in turn will create the political pressure for governments and nongovernmental organizations to take action. ${ }^{62}$ The approach may need to be specific to each country and/or region. Moreover, it will be important to understand how the evidence can be translated into policy options that suit particular government ideologies and bureaucratic contexts and processes - again, something that will vary around the world. Evidence alone is insufficient for driving policy change, and in the absence of a detailed understanding of political and policy contexts, it will be difficult to make progress toward addressing this most important of issues.

\section{Acknowledgment}

The authors gratefully acknowledge Tina Price for administrative assistance in conducting the review.

\section{Author contributions}

$\mathrm{AJ}, \mathrm{JH}$, and TH conceived the review protocol, JH coordinated the database search and undertook data extraction, all authors were responsible for interpretation of data, $\mathrm{AJ}$ drafted the manuscript, and all authors were responsible for revising it critically for important intellectual content.

\section{Disclosure}

The authors report no conflicts of interest in this work.

\section{References}

1. Australia Institute of Health and Welfare. Australia's Health 2008. AIHW Cat. No. AUS 99. Canberra: AIHW; 2008.

2. McMichael AJ, Powles JW, Butler CD, Uauy R. Food, livestock production, energy, climate change, and health. Lancet. 2007;370(9594): 1253-1263.

3. Khan S, Hanjra MA. Footprints of water and energy inputs in food production - global perspectives. Food Policy. 2009;34(2):130-140.

4. Ericksen PJ, Ingram JSI, Liverman DM. Food security and global environmental change: emerging challenges. Environ Sci Policy. 2009;12(4):373-377. 
5. Elferink EV, Nonhebel S, Moll HC. Feeding livestock food residue and the consequences for the environmental impact of meat. J Clean Prod. 2008;16(12):1227-1233.

6. Gunasekera D, Tulloh C, Ford M, Heyhoe S. Climate change: opportunities and challenges in Australian agriculture. In: Australian Bureau of Agricultural and Resource Economics; 2008; Canberra.

7. Garnett T. Livestock-related greenhouse gas emissions: impacts and options for policy makers. Environ Sci Policy. 2009;12(4):491-503.

8. Berners-Lee M, Hoolohan C, Cammack H, Hewitt CN. The relative greenhouse gas impacts of realistic dietary choices. Energy Policy. 2012;43:184-190

9. Garnett T. Cooking up a Storm: Food, Greenhouse Gas Emissions and our Changing Climate. UK: Centre for Environmental Strategy, University of Surrey; 2008.

10. Bradbear C, Friel S. Food Systems and Environmental Sustainability: A Review of the Australian Evidence. Canberra: Australian National University; 2011.

11. Vermeulen SJ, Campbell BM, Ingram JSI. Climate change and food systems. Annu Rev Environ Resour. 2012;37:195-222.

12. Aston LM, Smith JN, Powles JW. Impact of a reduced red and processed meat dietary pattern on disease risks and greenhouse gas emissions in the UK: a modelling study. BMJ Open. 2012;2(5):ii:e001072.

13. Geeraert F. Sustainability and dietary change: the implications of Swedish food consumption patterns 1960-2006. Int J Consum Stud. 2013;37(2):121-129.

14. Hallström E, Röös E, Börjesson P. Sustainable meat consumption: a quantitative analysis of nutritional intake, greenhouse gas emissions and land use from a Swedish perspective. Food Policy. 2014;47: 81-90.

15. Hendrie GA, Ridoutt BG, Wiedmann TO, Noakes M. Greenhouse gas emissions and the Australian diet - comparing dietary recommendations with average intakes. Nutrients. 2014;6(1):289-303.

16. Macdiarmid JI, Kyle J, Horgan GW, et al. Sustainable diets for the future: can we contribute to reducing greenhouse gas emissions by eating a healthy diet? Am J Clin Nutr. 2012;96(3):632-639.

17. Masset G, Vieux F, Verger EO, Soler LG, Touazi D, Darmon N. Reducing energy intake and energy density for a sustainable diet: a study based on self-selected diets in French adults. Am J Clin Nutr. 2014;99(6):1460-1469.

18. Meier T, Christen O. Environmental impacts of dietary recommendations and dietary styles: Germany as an example. Environ Sci Technol. 2013;47(2):877-888.

19. Pairotti MB, Cerutti AK, Martini F, Vesce E, Padovan D, Beltramo R. Energy consumption and GHG emission of the Mediterranean diet: a systemic assessment using a hybrid LCA-IO method. Journal of Cleaner Production. 2014:1-10.

20. Pathak H, Jain N, Bhatia A, Patel J, Aggarwal PK. Carbon footprints of Indian food items. Agric Ecosyst Environ. 2010;139(1-2):66-73.

21. Risku-Norja H, Hietala R, Virtanen H, Ketomaki H, Helenius J. Localisation of primary food production in Finland: production potential and environmental impacts of food consumption patterns. Agric Food Sci. 2008;17(2):127-145.

22. Risku-Norja H, Kurppa S, Helenius J. Dietary choices and greenhouse gas emissions - Assessment of impact of vegetarian and organic options at national scale. Prog Ind Ecol. 2009;6(4):340-354.

23. Saxe H, Larsen TM, Mogensen L. The global warming potential of two healthy Nordic diets compared with the average Danish diet. Clim Change. 2013;116(2):249-262.

24. Scarborough P, Appleby PN, Mizdrak A, et al. Dietary greenhouse gas emissions of meat-eaters, fish-eaters, vegetarians and vegans in the UK. Climatic Change. 2014.

25. Soret S, Mejia A, Batech M, Jaceldo-Siegl K, Harwatt H, Sabaté J. Climate change mitigation and health effects of varied dietary patterns in real-life settings throughout North America. Am J Clin Nutr. 2014; $100: 490$ S-495S

26. Tukker A, Goldbohm RA, de Koning A, et al. Environmental impacts of changes to healthier diets in Europe. Ecol Econ. 2011;70(10): $1776-1788$
27. van Dooren C, Marinussen M, Blonk H, Aiking H, Vellinga P. Exploring dietary guidelines based on ecological and nutritional values: a comparison of six dietary patterns. Food Policy. 2014;44: $36-46$.

28. Vieux F, Darmon N, Touazi D, Soler LG. Greenhouse gas emissions of self-selected individual diets in France: changing the diet structure or consuming less? Ecol Econ. 2012;75:91-101.

29. Westhoek H, Lesschen JP, Rood T, et al. Food choices, health and environment: effects of cutting Europe's meat and dairy intake. Global Environ Change. 2014;26(1):196-205.

30. Wilson N, Nghiem N, Ni Mhurchu C, Eyles H, Baker MG, Blakely T. Foods and dietary patterns that are healthy, low-cost, and environmentally sustainable: a case study of optimization modeling for New Zealand. PLoS One. 2013;8(3):e59648.

31. Hoolohan C, Berners-Lee M, McKinstry-West J, Hewitt CN. Mitigating the greenhouse gas emissions embodied in food through realistic consumer choices. Energy Policy. 2013;63:1065-1074.

32. Horne R, Grant T, Verghese K. Life Cycle Assessment: Principles, Practice and Prospects. Collingwood: CSIRO Publishing; 2009.

33. Raphaely T, Marinova D. Flexitarianism: decarbonising through flexible vegetarianism. Renew Energy. 2014;67:90-96.

34. Hedenus F, Wirsenius S, Johansson DJA. The importance of reduced meat and dairy consumption for meeting stringent climate change targets. Clim Change. 2014;124(1-2):79-91.

35. Popp A, Lotze-Campen H, Bodirsky B. Food consumption, diet shifts and associated non- $\mathrm{CO}_{2}$ greenhouse gases from agricultural production. Global Environ Change. 2010;20(3):451-462.

36. Pradhan P, Reusser DE, Kropp JP. Embodied greenhouse gas emissions in diets. PLoS One. 2013;8(5):e62228.

37. Stehfest E, Bouwman L, van Vuuren DP, den Elzen MGJ, Eickhout B, Kabat P. Climate benefits of changing diet. Clim Change. 2009;95(1-2): 83-102.

38. Thomson AM, Calvin KV, Chini LP, et al. Importance of food-demand management for climate mitigation. Nat Clim Change. 2014;4: 924-929.

39. Eshel G, Shepon A, Makov T, Milo R. Land, irrigation water, greenhouse gas, and reactive nitrogen burdens of meat, eggs, and dairy production in the United States. Proc Natl Acad Sci U S A. 2014;111(33):11996-12001.

40. Perry CL, McGuire MT, Neumark-Sztainer D, Story M. Characteristics of vegetarian adolescents in a multiethnic urban population. $J$ Adolesc Health. 2001;29(6):406-416.

41. American Dietetic Association. Position of the American dietetic association and dieticians of Canada: vegetarian diets. J Am Diet Assoc. 2003;103(6):748-764.

42. Sabate J, Rajaram S. Health benefits of a vegetarian diet. Nutrition. 2000;16:3.

43. Willett W. Lessons from dietary studies in Adventists and questions for the future. Am J Clin Nutr. 2003;78:4.

44. Whitney E, Rolfes S. Understanding Nutrition. 11th ed. Belmont, CA, USA: Wadsworth; 2008.

45. Segasothy M, Phillips PA. Vegetarian diet: panacea for modern lifestyle diseases? QJM. 1999;92(9):531-544.

46. Lanou AJ. Should dairy be recommended as part of a healthy vegetarian diet? Counterpoint. Am J Clin Nutr. 2009;89(5):1638S-1642S.

47. Baines S, Powers J, Brown WJ. How does the health and well-being of young Australian vegetarian and semi-vegetarian women compare with non-vegetarians? Public Health Nutr. 2007;10(5):436-442.

48. Greene-Finestone LS, Campbell MK, Evers SE, Gutmanis IA. Attitudes and health behaviours of young adolescent omnivores and vegetarians: a school-based study. Appetite. 2008;51(1):104-110.

49. O'Dea JA. Prevention of child obesity: 'first, do no harm". Health Educ Res. 2005;20(2):259-265.

50. Popkin BM. Reducing meat consumption has multiple benefits for the world's health. Arch Intern Med. 2009;169(6):543-545.

51. Kingdon JD. Agendas, Alternatives and Public Policies. Boston: Little, Brown and Company; 1985. 
52. Kickert WJM, Klijn E, Koppenjan JFM. Management perspective on policy networks. In: Walter JM, Kickert E-H, Koppenjan JFM, editors. Managing Complex Networks: Strategies for the Public Sector. London: Sage; 1997:224.

53. Verdung E. Policy instruments: typologies and theories. In: BemelmansVidec ML, Rist RC, Vedung E, editors. Carrots, Sticks and Sermons. Policy Instruments and Their Evaluation. New Brunswick: Transaction; 2007:103-128.

54. Salonen AO, Helne TT. Vegetarian diets: a way towards a sustainable society. J Sustainable Dev. 2012;5(6):10-24.

55. Robinson TN. Save the world, prevent obesity: piggybacking on existing social and ideological movement. Obesity. 2010;18:S17-S22.

56. Dagevos H, Voordouw J. Sustainability and meat consumption: is reduction realistic. Sustainability Sci Pract Policy. 2013;9(2):60-69.

57. Scarborough P, Allender S, Clarke D, Wickramasinghe K, Rayner M Modelling the health impact of environmentally sustainable dietary scenarios in the UK. Eur J Clin Nutr. 2012;66(6):710-715.
58. Steinfeld H, Gerber P, Wassenaar T, Castel V, Rosales M, de Haan C. Livestock's Long Shadow: Environmental Issues and Options. Rome: Food and Agricultural Organization of the United Nations; 2006.

59. Barosh L, Friel S, Engelhardt K, Chan L. The cost of a healthy and sustainable diet - who can afford it? Aust $N$ Z J Public Health. 2014;38:7-12.

60. Temple NJ, Steyn NP. The cost of a healthy diet: a South African perspective. Nutrition. 2011;27:505-508.

61. Joyce A, Dixon S, Comfort J, Hallett J. Reducing the environmental impact of dietary choice: perspectives from a behavioural and social change approach. J Environ Public Health. 2012;2012:978672.

62. Clavier C, de Leeuw E. Health Promotion and the Policy Process. Oxford: Oxford University Press; 2013.
Energy and Emission Control Technologies

\section{Publish your work in this journal}

Energy and Emission Control Technologies is an international, peer-reviewed, open access journal publishing original research, reviews, editorials and commentaries on developing technologies to optimize energy production and control of emissions. The manuscript management system is completely online and includes

\section{Dovepress}

a very quick and fair peer-review system, which is all easy to use. Visit http://www.dovepress.com/testimonials.php to read real quotes from published authors.

Submit your manuscript here: http://www.dovepress.com/energy-and-emission-control-technologies-journal 